\title{
Third Camp Politics: An Interview with Phyllis and Julius Jacobson
}

\author{
Kent Worcester, Marymount Manhattan College
}

Phyllis Jacobson (1922-2010) and Julius Jacobson (1922-2003) were socialist activists in New York City from the mid-1930s through the first years of the twenty-first century. They were members of a radical generation that came of age during the great depression and embraced the language of socialism, communism, and Marxism. They were also the children of working class Jewish immigrants who grew up in the city's outer boroughs. For their parents, the First World War, the Bolshevik Revolution, and the general strikes and mass uprisings that convulsed many countries after the war were all recent events. The near collapse of the global economy in the early 1930s confirmed for many of their cohort the basic assumption that capitalism was inherently impermanent. Adopting a socialist outlook in a period characterized by social upheaval and economic crisis was easy; the challenge had to do with selecting a suitable group or tendency from a fissiparous menu of options.

In contrast to many of their peers, both Phyllis and Julius were instinctively critical of the Communist Party and those sections of the left that expressed political solidarity with the U.S.S.R. As teenagers they gravitated toward the much smaller Trotskyist movement, which is where they first met. By the time they were adults they had decisively broken with anything resembling an orthodox Trotskyist position. They remained active on the radical left, however, and helped carve out an independent socialist perspective that was grounded in a democratic interpretation of Marxism. Their pro-labor, pro-human rights, antiauthoritarian, and anti-capitalist worldview continues to find expression in the pages of New Politics, an independently published "journal of socialist thought" that they launched in 1961 and edited for many years. During the first half of their lives, they came of age, fell in love, and were active in a succession of socialist organizations. During the second half, their lives revolved around their magazine, book projects, friendships, summer travels, and their son. The interview that follows tracks their political trajectory from Trotskyism to third camp socialism, and offers a window onto their lively and engaging personalities as well as their principles and values.

Like many leftists of their generation, the Jacobsons were comfortable referring to themselves as radicals, socialists, or even Marxists. But they often used the term "third camp socialist," which might not be familiar to some readers. Neither Trotskyists nor Communists were keen on this terminology. Trotsky and his followers viewed the Soviet Union as a "degenerated workers state" and saw it as an improvement on the capitalist West, despite its cruel bureaucratic 
excesses. They called for the "defense" of the Soviet Union. Communists, meanwhile, regarded "Trotskyites" and so-called "anti-Stalinists" as red-baiters who were objectively working on behalf of the State Department, and later on the CIA. In this context, the term "third camp" was used by people like the Jacobsons to distinguish their preferred form of socialism from both the Soviet model and either U.S.-style Democratic Party liberalism or electoral socialism, otherwise known as social democracy. It was within this third camp milieu that the phrase "neither Washington nor Moscow, but international socialism" was first coined.

A key figure in this story is that of Max Shachtman (1904-1972), their longtime friend and mentor. Along with James P. Cannon, Shachtman was a leading Trotskyist during the 1930s and one of the movement's public faces. He had been active in the Communist Party in the 1920s and early 1930s, and was close to Cannon for much of this time. By the late 1930s, however, Shachtman had developed deep misgivings about Cannon's approach to party building and about the Trotskyist line on the degenerated-but-ultimately-progressive nature of the Soviet Union. The Jacobsons were closely aligned with Shachtman during the resulting 1939-1940 factional battle inside the Socialist Workers Party (U.S.). While Shachtman's supporters constituted a minority of party members, they enjoyed the vocal support of a majority of the party's youth wing. Expelled in 1940, Shachtman's faction quickly launched the Workers Party (1940-1949) and then the Independent Socialist League (1949-1958). Shachtman continued to regard himself as a democratic socialist after the ISL disbanded, he became increasingly supportive of U.S. foreign policy during the nineteen-sixties and worked behind-the-scenes as an advisor to hawkish, pro-war forces inside the ranks of organized labor and the Democratic Party.

Prior to Shachtman's tack to the right, the Jacobsons collaborated with the one-time Trotskyist spokesman in building the Workers Party and the ISL. They contributed articles and essays to Labor Action, the tendency's newspaper, as well as The New International, its theoretical magazine. In addition to its regular publications, the Shachtmanites hosted public meetings, conducted labor solidarity campaigns, sold pamphlets and books, maintained rank-and-file caucuses in a number of workplaces, and sponsored candidates in a couple of NYC electoral races in the mid-1940s. Julius and Phyllis participated in most if not all of these activities. During the war, Phyllis worked as a machinist in Brooklyn, and was active in her union and inside the organization. Her husband served in the U.S. Army between 1943 and 1945, taking part in the Battle of the Bulge and the liberation of Paris. After the war, he played a key role in launching the party's youth wing, the Socialist Youth League, using the pen name Julius Falk. He was the founding editor of the League's magazine, Anvil (1952-1960), and subsequently served as editor of New International, which folded at the end of the 1950s, when the ISL dissolved itself into the Socialist Party. By this point the Jacobsons were 
personally familiar with a wide swathe of the non-Communist left in and around NYC. Some of the writers and intellectuals who spent time in their company at one time or another in the midcentury period included the literary critic Irving Howe, the Marxist theorist Hal Draper, the labor journalist B.J. Widick, the novelist Harvey Swados, the painter and cartoonist Jesse Cohen ("Carlo"), the civil rights activist Bayard Rustin, the political scientist Bogdan Denitch, and the bestselling author and speaker Michael Harrington.

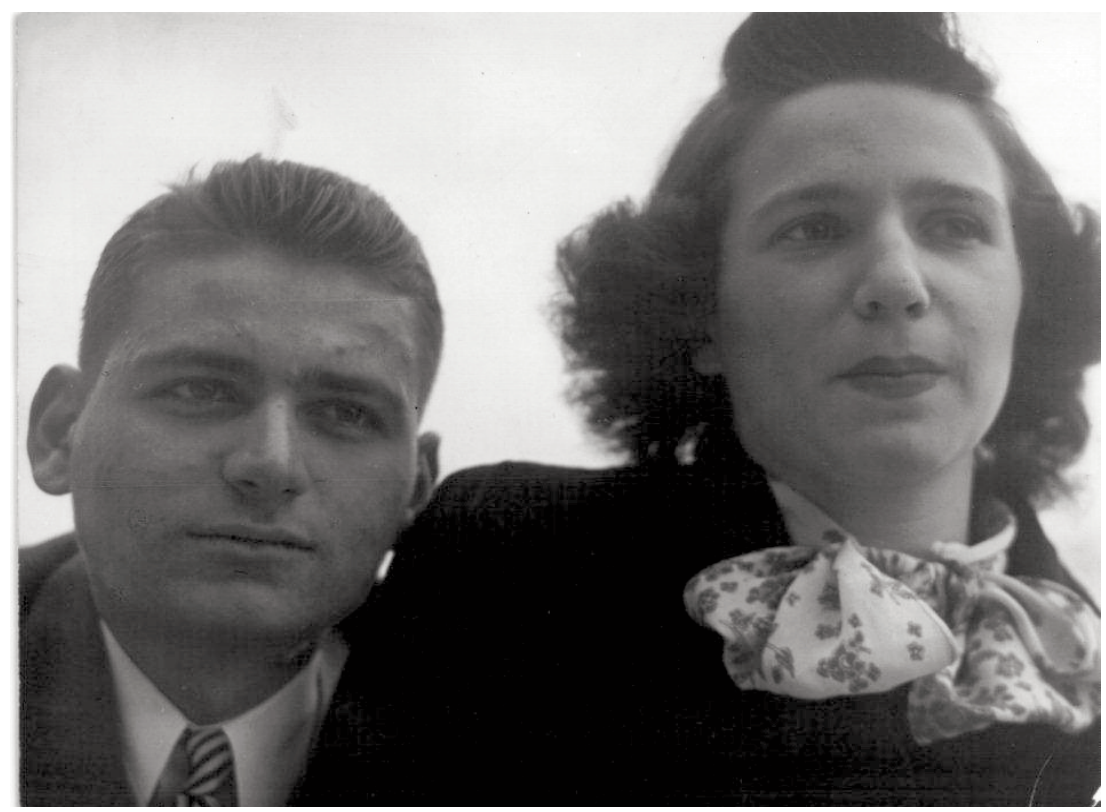

Figure 1, Julius and Phyllis Jacobson, New York City, c.19421

Following their break with Shachtman, the Jacobsons launched New Politics, in hopes of providing a "forum permitting and encouraging a free play of discussion, controversy and counterposition of ideas ... [and] an opportunity for all socialist views from the left to right to confront not only the political reality but also each other and their critics" ("Why We Publish," issue \#1). The impressive momentum achieved by the civil rights movement, and the emergence of campus-based and anti-war movements, put wind in their sails. From the journal's inception, Julius served as the editor-in-chief in tandem with a small editorial board and a larger number of sponsors. Phyllis's name was officially added to the editorial board in 1968, but she had been closely involved with its development from the outset. Forty-five issues of NP appeared between 19611978 before the Jacobsons suspended publication. Detecting a revival of interest in leftwing ideas, Phyllis and Julius relaunched the journal in 1986. The print ver- 
sion currently appears twice a year, and the editorial board maintains a website and multi-authored blog at www.newpol.org. In the early 1980s the Jacobsons coedited a book, Socialist Perspectives (1983), which represented a trial run for the new series. Julius had previously put together two collections of articles taken from NP, The Negro and the American Labor Movement (1968) and Soviet Communism and the Socialist Vision (1972). A third collection, Autocracy and Insurgency in Organized Labor (1972) was edited by Burton Hall, a pen name for the magazine's longtime contributor Herman Benson. Additional bibliographic resources are listed in the "Notes" section that appends the interview.

This interview is taken from three taped conversations with Phyllis and Julius Jacobson that the author conducted in November 1992, September 1994, and November 1994. It incorporates, with permission, a small amount of material from an interview conducted by the labor historian Jon Bloom in November 1983. Eleven of Julius's articles and reviews are posted on the Marxists Internet Archive, at www.marxists.org / history/etol/writers/Jacobson, and New Politics maintains a collection of articles and reviews by Phyllis, at www.newpol.org/content/phyllis-jacobson-1922-2010.

\section{Section 1: Joining the Movement}

WORCESTER: Tell me how you came to join the movement.

JULIUS JACOBSON: I was brought up in New York during the depression. Virtually everyone was a radical then - a Communist, socialist, social democrat, or Trotskyist. You were something. My parents were born in Latvia and met each other in England. They later migrated to the United States. We lived in the Bronx. It was a period of rent strikes, housing evictions, and demonstrations. That was the atmosphere when I grew up.

I joined the Young Pioneers, which was the junior section of the Communist Party, but I broke away at the age of thirteen. That was young, but it wasn't all that unusual. What was unusual was to break away from the Young Pioneers and to join a Trotskyist organization, after which, of course, I was persona non grata. The other children already had the mentality of older Stalinists. I lost all my friends. My Aunt Bessie, who was a third period Stalinist - she was out of her mind...

PHYLLIS JACOBSON: ... she truly was...

J. JACOBSON: Anyway, she loved me dearly, but would not talk to me, which will give you a flavor of those years. At that point I went into the Socialist Party's Young People's Socialist League, as a member of the Trotskyist faction. Two years later we split from the Socialist Party, which I think was a mistake. 
The split came about as a result of Trotsky's pressure. I don't think that either [James] Cannon or [Max] Shachtman were for it. But we did have differences with the Socialist Party over the question of the Spanish Civil War, and in those days everything became a split issue.

P. JACOBSON: Yes, well, I came out of a different background than Julie did. My father was born in a part of Austria that had previously been Poland and came here as a very young man. Like many Europeans of his generation, he was a social democrat. He worked as a waiter. My sister and I grew up in a household where you had to be a union person and a socialist. That was the temper of the times. I joined the Young People's Socialist League when I was in high school. I must have been about fourteen. The high school I attended, in Bensonhurst, had a large number of Communist teachers. Many later on were victims of McCarthyism. But some of them were absolutely intolerant of opposing ideas. And when I went to Brooklyn College, there were a number of professors who were close to or members of the CP.

Some of the faculty were really terrible. It became a battle of wits. You had people like V., who would say, "If there's any member of the Trotskyite flea circus here, I suggest they leave." This was a professor of English, one of the country's foremost Shakespeare scholars. But you have to understand that at Brooklyn College in that period - I was there from 1938 to 1942 - many students were involved in radical activities. When you went to school on Wednesday, which was the day for extra-curricular activities, you walked through a gauntlet of political clubs and sects, some of which I'm sure you've never heard of. And everyone took it all very seriously. Students read the material; they were up on exactly what was going on. That was the nature of the period.

We had a fairly large group at Brooklyn College as such groups went. We must have had about thirty members, and a fair number of sympathizers. We had very good meetings. Shachtman would regularly speak on campus, as did other party leaders.

The war broke out while I was still at college, and when I left school, I went to work in a factory. The factory was in Hoboken, and I worked alongside a CPer, who would hand me pamphlets by Clara Zetkin on the woman question. This guy turned out to be Murray Handwerker, who went on to become the owner of Nathan's Famous. His father founded Nathan's but had disowned his son, because he joined Nathan's workers on the picket line when they were organizing.

After a while I got a job at Sperry, which was difficult, because it turned out that I scored too high on the test. That was a problem for many comrades. When you went to these large factories they gave you some sort of test, part of which was written and part of which concerned manual dexterity and so on. It was hard to suppress what you knew, so most people scored a little 
high, and they were very suspicious if you scored well on the test. I don't know what lies I told them; I certainly didn't tell them I had gone to college. But I was hired at Sperry and went to work in the shop, which was a lively place. I started out as an inspector but after a very short time I became a first piece inspector, which was interesting, because what I had to do was to check the first piece of work that came off a machine to make certain the machine was set up properly. I had to read blueprints, and had to work with inspection materials, dial indicators, and so on. At first the other workers didn't very much like the notion of having a woman as a first piece inspector. But I didn't earn as much as they did. I still remember that I earned 85 cents an hour, while a man doing the same work earned \$1.25. And we had to work nine hours a day, six days a week.

J. JACOBSON: When I graduated from high school, things were very rough. I used to work part-time jobs at the weekend and so on. At that point the Socialist Workers Party (SWP) had opened up a print shop and it was determined that I would go through the training program offered by the New York School of Printing. After three or four months at the School I went to work as a compositor at the party print shop. As a compositor I made up the pages of the Socialist Appeal, the New International, the pamphlets, and so on. The shop consisted of a group of around 6 or 7 comrades. We had 2 linotypists, 2 pressmen, a compositor, and someone doing the secretarial work. It was organized as a regular shop. P. JACOBSON: There was a strike in the party print shop!

J. JACOBSON: Don't be hilarious. But we were making around eight dollars a week, or something like that. It wasn't very much, but, after all, we were considered professional revolutionaries. At a certain point, however, a number of us felt we should get something a little more substantial than what we were getting, that the party could afford another 2 or 3 dollars. We met with Shachtman, and presented our grievances. Max said, oh no, the party can't afford it. We argued back and forth. I don't remember if it ever got to the point where we downed tools, but we certainly threatened, and there were all sorts of negotiations and finally we won our demands.

As far as dues were concerned, we had a progressive tax system...

P. JACOBSON: ... based on what you earned...

J. JACOBSON: ... where you had to tell the party how much you earned and pay a percentage of that.

P. JACOBSON: Everyone accepted that.

J. JACOBSON: It was the least you could do. But, more importantly, you had to 
be active in the movement - three, four, five nights a week.

WORCESTER: This was just before the 1939-1940 split between the Cannon camp and the Shachtmanites.

J. JACOBSON: It was Trotsky who really wanted to split the organization. He would not tolerate the Shachtman minority. The Shachtman position, which repudiated the idea that the Soviet Union should be defended in any way, involved a fundamental issue. To Trotsky it meant repudiating the idea of Russia as a degenerated workers' state. And he was right. That was the implication of our point of view, although Shachtman never rejected the idea of Russia being a genuine workers' state until after the split. The longer the faction fight went on, the weaker Cannon's position became. The debates were one-sided, and history was on the side of the Shachtmanites. The entire youth section, which was the most dynamic part of the movement...

P. JACOBSON: ... were Shachtmanite. It was very sad for us, because you have to remember that despite the fact that we were very critical of Cannon, we were very saddened, because Cannon was a very important figure in the movement. Aside from everything else, he was a very romantic figure. He was a wonderful speaker who could quote Keats, Shelley, the great poets. He was a nineteenth century type of orator, unlike Shachtman or C.L.R. James, who were also important speakers. And it saddened us to see that Shachtman, who was brilliant, could make him look foolish.

J. JACOBSON: It was painful.

P. JACOBSON: Because he knew nothing about theory.

WORCESTER: But he knew something about America.

P. JACOBSON: Yes he did. He knew something about the labor movement. However, it has to be said that there was something tremendously anti-intellectual about the Cannon group.

\section{Section 2: The Workers Party during the War}

J. JACOBSON: So that was one big change, but some things stayed the same. When the Workers Party (WP) was organized, we called ourselves a party, and we thought of ourselves as a small mass party. It was an illusion that was very hard to sustain, because the reality was that we were not a party. We were not recruiting large numbers of people, even though we were very active in the factories during the war. For an organization our size we had a real impact, particular in 
the United Auto Workers union, and somewhat in the United Electrical Workers (UE), and more generally as a political force inside the labor movement. But the fact is that we did not emerge out of all this as a party. We did recruit, but we weren't able to hold on to a lot of the people we recruited from the shops. And by 1947 or 1948 it dawned on us that it was very demoralizing to call ourselves a party and yet not to be a party. This was the point at which we transformed ourselves into the Independent Socialist League. What it meant was acknowledging the reality of what we were, and what it meant in terms of becoming a somewhat looser organization.

There were some things we did as the Workers Party which we never would have done operating as a league. For example, in the early years we had a policy of sending our members, mostly young people, into industry. And it was wrong, because a lot of people weren't psychologically prepared for it. People were talked into leaving white collar jobs, or college, to take jobs in shops.

P. JACOBSON: One of the aims of the industrialization policy was to catch up with what the Communist Party had done much earlier. After all, the CP had been very successful in sending their people into the factories and helping to organize the CIO. We also told people that they had to leave New York and go to Cleveland, or Detroit, or Buffalo, which is what people did.

WORCESTER: What were your expectations about the war, and about the direction in which the country would go after the war ended?

J. JACOBSON: Our point of view shifted. When the war broke out we adopted a misguided point of view, which was that in the course of the war America would become a fascist state, that it could not fight a democratic war in a democratic way, and that the consequences of such a war would be such that we would end up with a dictatorship. And that become one of the reasons for our opposition to the war.

WORCESTER: Did you see Roosevelt as a potential fascist?

J. JACOBSON: It wasn't so much Roosevelt as a transformation of the whole society. We anticipated that under the pressure of war there would be a suppression of trade unions...

P. JACOBSON: ... of free speech...

J. JACOBSON: ... and that there would be a militarization of American life.

Once everyone realized that it was going to be a long war, that Germany was not about to be thrown back, we expected that in the context of the war against fascism we would wind up becoming a fascist society ourselves. We had meetings 
on this subject, and drafted resolutions. We denounced the war. That was one difference between us and the SWP. The SWP had a similar point of view. But they also had a policy of "preserving the cadre." And so they laid low.

WORCESTER: What did opposition to the war mean in practice?

J. JACOBSON: It meant, for one thing, the way in which we characterized the war. We always used to put the question in the following terms: if you were a member of Congress, how would you vote when it came to war appropriations? This was a sort of fancy way of looking at the problem. But the idea was, it was a way of testing your position. And we said no. We held the view that the revolutionary left held during World War I. And in that of course we were wrong.

WORCESTER: Why?

J. JACOBSON: Well, for one thing America did not become a fascist society. Also, we didn't take into consideration the stark differences between Nazism and the German system in World War I. It was wrong to see this kind of equivalency between the contending forces.

P. JACOBSON: That could only be rationalized by saying that bourgeois democracy would not remain democratic for very long.

J. JACOBSON: We said sure there's a difference. We did not claim that bourgeois rule was the same as fascism. But we also said that you had to look at it dynamically, and recognize that in the course of the war bourgeois democracy would not be able to survive.

P. JACOBSON: There's something else to consider. When your generation thinks about opposition to a war, you think of Vietnam. And opposition to the Vietnam War meant refusing to serve in the army. But that was never true for us during World War II. Quite the contrary. Everyone served. Shachtman was furious later on, during the Korean War, when young people in the movement did everything they could not to serve. His attitude was quite despicable. He said they were cowards and yellow-bellies. He equated it with homosexuality. He was very homophobic.

J. JACOBSON: Another important difference between the world wars was that even before World War II started it was obvious that Germany had the aim of colonizing the countries it defeated in battle. And that was not an operative factor during World War I. Germany didn't try to make a colony out of France, and France didn't intend to make a colony out of Germany. But this time things were different. 
I still don't think that the pro-war position was correct either. Even at the time, if you had put a pistol to my head and said you have to make a choice, who do you want to win, the Allies or the Axis, I would have said the Allies. But opposition to the war meant supporting the class struggle. During the war you had authentic social democrats who wanted to reduce the level of struggle. That became a big consideration. "Well, a strike - how's that going to affect production?" "You want to make an issue of the segregated army, but how's that going to affect morale?" And that was not a consideration for us. The way we developed the antiwar point of view, in publications and in person, was you prosecute the class struggle, and the struggle for social justice. You make no concessions.

WORCESTER: Did you run across fascists in the United States?

J. JACOBSON: We used to fight with them. Before I joined the army, I worked alongside them at GE, in the repair shop. Everyone there was a skilled worker, and many of them were German-Americans. Things were so bad that when I used to wash up after a day's work I carried a knife with me.

WORCESTER: Labor Action, the Workers Party weekly newspaper, was distributed in the tens of thousands during the war.

P. JACOBSON: It was given out at factory gates, and in housing projects. One of the things we did was go around to various places to try to meet as many people as possible. The idea was that it was possible to build a mass party. A primary locus of activity was giving Labor Action out at factory gates. Harvey Swados writes about this in his novel Standing Fast [1970].

WORCESTER: What kind of people were coming around the party during the war?

P. JACOBSON: During the war we attracted people through our activity in the shops. It was very sad. A lot of them were drawn to the Workers Party through the activity of those who were in leadership roles in rank-and-file opposition groups, but there was no real life for them. One of the advantages for the CP was that they started with a movement which was large enough to provide new members with some sort of social life. We couldn't compete in that regard. We had one member, Max, who was an important figure in the UE. He was very smart and enormously successful. He really knew how to explain to workers about how the unions and companies operated. He organized a huge opposition caucus and was able to bring all kinds of people around the Workers Party. 
J. JACOBSON: The people he brought around were working people and they weren't intellectuals. They would prefer to go on a Saturday night to a bar and have a beer, while we preferred to go to Greenwich Village and listen to jazz

music. They would come around but the movement became like a revolving door. And that went on for years.

P. JACOBSON: Of course, during the war it was the women members who basically had to maintain the organization in a very practical way. But they also worked. I can't think of one person who stayed at home. Never.

WORCESTER: Did you consider yourself a feminist? Were you comfortable with the term?

P. JACOBSON: Oh yes, absolutely. As a matter of fact I kept my own name. I did not use Julie's name. My name was Phyllis Garden. I used my own name at work. It wasn't until the 1960s when some bookkeeper where I was working said, "Look, you're going to get in trouble because they're going to find a maiden name and a married name and you'll have trouble with Social Security." So for that purpose I started to use my married name.

J. JACOBSON: We had reasonably decent attitudes. It's not that the attitude was bad, but the behavior was bad.

P. JACOBSON: Yeah. We did know some outstanding feminists who were not necessarily in our movement but who were radicals. There were a number of such women in New York. But there were very few women in the leadership of the WP.

J. JACOBSON: Women were always the ones who had to type up the resolutions.

P. JACOBSON: Secretaries.

J. JACOBSON: It was assumed that at every meeting, you needed someone to take the minutes, and it was assumed that the minutes would be taken by a woman.

P. JACOBSON: They played the same role as the women in the New Left, until the women in the New Left became bold and said, "we're not going to make coffee anymore."

WORCESTER: How would you respond to the idea that groups like the Workers Party served as a kind of vehicle for immigrant intellectuals who even- 
tually assimilated into American society?

P. JACOBSON: If you think of people in the 1950s, people who had been around our movement who wound up as, say, academics, it was not only because the movement funneled them into the mainstream of American life. What was really going on was that in the 1930s and 1940s there were very few stable jobs. If you were a college graduate, you were lucky if you got a job standing behind a counter in a department store. Most of the young comrades were unemployed.

J. JACOBSON: And they weren't equipped to work in factories.

P. JACOBSON: That's right. Our old friend Dave was very lucky because he worked for the City of New York, and he was rich by our standards. He made something like $\$ 30$ a week. That was a great deal of money.

\section{Section 3: After the War}

J. JACOBSON: Like many others, I was eventually drafted into the army. I came back in March of 1946, and went back to work for GE, where I worked for about eight months before I quit to become a Socialist Youth League (SYL) functionary. What happened was that in 1945 the WP decided that this was the time to organize a socialist youth group. And the feeling was that the high schools were the places to organize. Needless to say, this was done with minimal success. When I got back in '46, Shachtman urged me to take the job as youth organizer. I told him that so long as you have the illusion of recruiting working class kids out of high school, you're not going to get anywhere. The only kind of youth movement you could build would be middle class, involving college kids.

I would feel that way even today, that a leftist group would have trouble holding onto adult workers or teenagers from working class backgrounds. It's a very difficult thing for a worker without a profound ideological commitment to join a sectarian group and to remain in it for an extended period of time. We had nothing to offer them. We had our ideas, our idealism, and that would only have a certain attraction for a limited period of time.

WORCESTER: What kind of work were you able to find after the war?

P. JACOBSON: We lived very frugally because Julie worked for the organization for the longest period of time. I did some part-time work, such as reading scripts for the movies. Don't ask.

WORCESTER: I think I have to.

P. JACOBSON: I worked at that for years. 
J. JACOBSON: It all started because a friend of mine had starting reading stuff for one of the movie companies. It turns out that what they did was to read almost every novel that came out and lots of non-fiction as well, and hired readers on a freelance basis to give a synopsis of the material, and to say whether it would be suitable for a film.

WORCESTER: Presumably most of this material was not suitable.

P. JACOBSON: That's right. And it struck me that it was a perfect activity because I could devote myself to the organization and work at this part time. In fact, Irving Howe and I were doing it at the exact same time for two different companies. We would call each other every day to find out who got what book, and then if we both got the same book we would simply use the other's material. You generally received galleys, which were not pleasant to read. Julie was working for the organization, and he was only getting five bucks a week. In order to recruit students, he signed up as a student at various institutions around the city. He really enjoyed the class he took at Columbia in mathematical logic.

J. JACOBSON: I liked it very much, and registered for the next advanced class, but it took up too much of my time, and I had to drop the class. The professor wanted to know why I was giving it up, I did so well.

WORCESTER: I read somewhere that after the war, Trotskyists became professors, and Communists became landlords.

P. JACOBSON: It's true! Businessmen!

J. JACOBSON: We were successful in building the Socialist Youth League in this period. I don't know that we ever had more than a couple hundred members nationally, but those couple hundred...

P. JACOBSON: ... were very active.

J. JACOBSON: Oh, it was fantastic. We were instrumental in putting out a publication called Anvil. There was a broadly similar publication out of Chicago called Student Partisan, which was founded in 1949. The two publications soon merged, and the new journal was titled Anvil and Student Partisan, although we usually referred to it as just Anvil. I finally left the SYL in 1950. I figured I was too old for it. But I served as the editor of Anvils first few issues.

P. JACOBSON: And so you were.

J. JACOBSON: Well, I was twenty-eight years old at the time, and so it was time 
for me to move on. And the next assignment for me was to become the managing editor of the New International.

P. JACOBSON: For many years we lived in a two-room apartment opposite the White Horse Tavern on $11^{\text {th }}$ and Hudson, in the Village. And then Julie and Herman Benson finally started a little machine shop of their own. Shachtman had this brilliant idea of making money for the movement by starting a long playing record society. The long playing record society was an imaginative Shachtman lunacy. He was very interested in the whole technology of hi-fi, and he saw this as a great opportunity to sell records. But of course you needed a staff, so the staff consisted of Max, his girlfriend, and me. Ben and Julie had a shop in one part of the building, on $14^{\text {th }}$ Street, and the other part was the long playing record society. Of course the whole thing was totally loony. And then Shachtman decided to go one step further, by setting up hi-fi equipment for friends and comrades.

J. JACOBSON: He was a natural schemer.

P. JACOBSON: Our office was located at 108 West $14^{\text {th }}$ Street, and the party headquarters was at 114 West $14^{\text {th }}$ Street, and so we would run back and forth between the headquarters and the hi-fi office.

WORCESTER: Where did you advertise this long-playing record society?

P. JACOBSON: I don't know that we did. We must have done something right because for a while it was making money. But it was an enormous amount of work.

WORCESTER: So when did you realize that...

P. JACOBSON: ...the revolution wasn't coming?

WORCESTER: The revolution wasn't coming.

P. JACOBSON: Very early on. Right after the war.

WORCESTER: Did you have a sense of comrades who were drifting out of the movement, and buying housings in the suburbs?

P. JACOBSON: Absolutely. Not so much that some were moving out to the suburbs, but also that some people were making scads of money. I mean really big money. We were both scornful and angry. Because they were getting to be dark days. People drifted, unlike the group that started Dissent, who said "we're leav- 
ing, we don't agree with you, and we're going to start our own thing." At least they remained political people.

J. JACOBSON: By the late 1950s, when we went into the Socialist Party, there was really nothing left.

P. JACOBSON: It was all gone.

J. JACOBSON: It sort of peaked during the war.

WORCESTER: Were you caught up in the fashion for Freudian ideas that caught on after the war?

P. JACOBSON: Yes, in the movement that was a very big thing.

J. JACOBSON: Everyone in our movement was interested in one aspect or another of psychoanalysis.

P. JACOBSON: And every other person around the movement was in therapy. But it meant they had less money to give, because they had to pay their therapist.

J. JACOBSON: I'd say in New York City there were maybe 80 or 90 members who were regularly going to therapy. Half the New York membership or something. It was almost considered a normal thing to do.

WORCESTER: When did you buy your first television set?

P. JACOBSON: We didn't get a TV until, well, our son must have been about twelve years old before we got a television set. It was in the mid-1960s.

WORCESTER: Was Shachtman a universally popular figure in the organization?

P. JACOBSON: Yes, he was. He was universally popular. He performed very well in public settings. Someone like Hal Draper was disadvantaged in this respect. He was remote. He was a wonderfully educated, brilliant guy, who had few real friends in the movement.

J. JACOBSON: He was alone.

P. JACOBSON: Draper's great fortune was that he was married to Anne, and Anne was an extremely warm, friendly person. Shachtman, on the other hand, was a dynamic figure. He had a mordant wit, and was an absolutely marvelous speaker. He was also a terribly undisciplined person. He couldn't really write properly. He wouldn't do the sorts of things he should have done, such as write 
pamphlets and books. He couldn't. He enjoyed talking, and manipulating an audience. He enjoyed displaying these flashes of brilliance. James Cannon was a much better leader of an organization. But Shachtman would suck you in.

J. JACOBSON: And you'd forgive him. He would do and say things that you would cut someone dead for, but if Max did it, you excused him. People allowed him to get away with things. He was a politician, and generally he was very sentimental.

P. JACOBSON: He was very warm.

J. JACOBSON: He was warm, he'd joke and cuss.

P. JACOBSON: If you ever saw him read a newspaper, he'd sit with the Times, he eyes would go over it, and he would absorb it almost by osmosis. He was also a bibliophile. His library consisted of...

J. JACOBSON: ... stolen books.

P. JACOBSON: Stolen books. If he came to our house, he would steal books. He would take them from everybody. He was very light-fingered. He felt that you had to give him things as his due, because after all he sacrificed himself for the movement.

\section{Section 4: From Max Shachtman to New Politics}

WORCESTER: Max Shachtman seems to have been largely responsible for the group's move into the Socialist Party (SP) at the end of the 1950s.

P. JACOBSON: We joined as individuals, and a number of people did not enter. I don't know that Julie ever entered. But I did. And Hal Draper didn't join the SP. Once we got into the Socialist Party, the right-wingers in the SP discovered that they had a made a huge error, that Shachtman had already developed a point of view that was far to the right of theirs. While they wanted to maintain an independent Socialist Party, Shachtman basically wanted to dissolve the SP into the Democratic Party. And the left-wingers, who mostly welcomed our entry into the Socialist Party, were really appalled. At some point we got word that Shachtman was trying to start a new magazine with Norman Thomas and Eric Fromm. They were...

J. JACOBSON: .... a strange trio...

P. JACOBSON: ... an odd couple. 
J. JACOBSON: The idea that Shachtman was going to work in a responsible way and collaborate with Thomas and Fromm was absurd.

P. JACOBSON: But other people, such as ourselves, were also thinking about starting a new publication. What was needed was a publication in which our views could be expressed that could reach beyond the usual milieu.

WORCESTER: When did you realize that there was going to be a New Left?

P. JACOBSON: We knew, of course, that there was already a growing civil rights movement. You could see that something was developing and we wanted to be a part of that.

WORCESTER: What kind of political perspective was this new journal going to promote? Were you thinking of a specifically Marxist journal?

P. JACOBSON: No.

\section{J. JACOBSON: Third Camp.}

P. JACOBSON: Third Camp and broad. We envisioned a Debsian kind of magazine. We were willing to work with social democrats and so forth. It was at this point, when we were formulating our plans that we went to Norman Thomas. Julie and I called his secretary. We decided at this point that truly in the Debsian spirit we would like to approach Norman Thomas. It was around this time that Shachtman showed up at our tiny apartment on $11^{\text {th }}$ Street and had dinner. He asked us why we were starting a magazine. He said, "Why do you want to do this? You know we have this wonderful project [with Thomas and Fromm]." And we said, "Well, you never told us you were doing it? How come you didn't inform us?" So he said, "You idiot, don't you realize, you [Julius] were going to be the editor." The man was the most incredible liar. "In any case, why do I have to inform you? I have you in my pocket."

J. JACOBSON: "My vest pocket." I mean that we will never forget.

P. JACOBSON: A vest pocket is after all a very small place. Anyway, that ended that. After that dinner, Shachtman started a real campaign against our project, bad mouthing us to Thomas and saying what terrible people we were. But Thomas being Thomas...

J. JACOBSON: ... was crucial to the project.

P. JACOBSON: Yes, we needed him very badly. 
WORCESTER: Why was that?

P. JACOBSON: Because Norman Thomas was such a towering figure in the socialist movement, and the left more generally.

J. JACOBSON: We were really interested in a broad magazine. Thomas' participation was a way of saying that this was not going to be another New International.

P. JACOBSON: Right. It's not the same old-time stuff.

WORCESTER: When did you decide to make a decisive break with the explicitly Marxist approach of New International?

J. JACOBSON: It wasn't a break. What carried over was the idea of a Third Camp. But it wasn't the Third Camp as developed by a revolutionary socialist Marxist tendency. It was time to create a publication in which those views could be expressed in...

P. JACOBSON: ... an open forum.

J. JACOBSON: In an open forum with others.

P. JACOBSON: We realized that the time was different. After all, we ended up as a sect with practically no members. We ended with zilch. We had nobody coming around. In any case, Norman Thomas welcomed us. He was very old, and we could see that he was very tired. But we started the discussion and Thomas sat there with an odd smile on his face, listening to what we had to say. He looked as though he was asleep some of the time, but he wasn't sleeping for a second. He had all his wits about him. We told him what we wanted to do, and urged him to give us his support. We told him that we wanted to have a broad publication, and Thomas said yes.

He also cast aspersions on Shachtman and his way of dealing with people. He was not at all happy with Shachtman's machinations. What he was saying in effect was, "I may look like an old fool, but you better believe that I'm not." And that did it.

J. JACOBSON: With that we made a formal announcement.

P. JACOBSON: I was a member of the Socialist Party's National Committee, and there was a meeting around this time in Philadelphia. At some point I asked the National Committee to let our new journal, which we decided to call New Politics, have access to the Socialist Party mailing list. Shachtman started making 
one of these absolutely Shachtmanesque speeches. "Why should we give them the mailing list? Who are these people who come in the dead of the night?" One of the old right-wingers in the Socialist Party took the floor, and said, "What are you talking about? These are your comrades. Phyllis and Julie Jacobson. What dead of night are you talking about?" The right-wingers were very offended. And so we did get the list. And of course that was a very good start because the SP had an extensive list at that point. And then we started promoting the magazine.

J. JACOBSON: Some of the early issues were quite good. Hal Draper wrote some very good articles for us. And the first issue of New Politics sold 3,000 or 4,000 copies.

P. JACOBSON: Yes. It was very thick. Julie always believes the bigger the better. But raising money was hard. We were always falling behind in terms of the publishing schedule, because we could not raise the necessary funds. Now mind, it was a quarterly, which is very difficult to sustain. One of the great difficulties had to do with getting proper distribution. Our distributor at the beginning was Eastern News. They placed it on some newsstands. The newsstand at $42^{\text {nd }}$ Street near $5^{\text {th }}$ Avenue used to sell a hundred copies per issue.

J. JACOBSON: But the way things worked out, the journal came out roughly three and a quarter times a year...

P. JACOBSON: ... instead of four. And I kept writing these wonderful letters to the post office, because they wanted to take away our second class mailing rights. We wrote fabulous double-talking letters, about why we were always late, but we held onto our rights.

WORCESTER: Was the journal read by members of SDS [Students for a Democratic Society]?

P. JACOBSON: Oh, I'm sure there were SDS members who read it.

J. JACOBSON: But the rank-and-file of SDS were not very big on reading intellectual journals. That was one of the tragic flaws of SDS. It was an anti-ideological movement in many ways.

P. JACOBSON: But the whole development of SDS...

J. JACOBSON: ... was a missed opportunity. 
P. JACOBSON: Of course, the Shachtmanites played an absolutely scandalous role vis-à-vis SDS.

J. JACOBSON: The hostility of the Shachtmanites, and the coldness of Michael Harrington and others, was such a put-off. Ironically, the one person in our movement who was really able to establish a rapport with SDS, and with the New Left, on a political and personal basis, was Hal Draper.

P. JACOBSON: Draper really did. He established a very good rapport with these young people.

J. JACOBSON: But for us, we wanted to put out an intellectual publication, and we had a completely different attitude about the New Left in comparison to people like Shachtman, Harrington, and Howe. But we couldn't really make contact with them, for various historical and political reasons.

WORCESTER: Did you have any kind of interaction with SWP members? Do you know if someone like James Cannon, for examples, saw the journal?

P. JACOBSON: Never. They subscribed. The party would get two copies of each issue, and to this day they receive two copies.

J. JACOBSON: That was a different world from us. We had no contact with them at all.

WORCESTER: How did you feel about the contrast between the early 1960s, a period in which socialist-humanist ideas flourished, and the late 1960s, when many young people were embracing all kinds of revolutionary fantasies?

P. JACOBSON: It was very demoralizing. We realized our time was up by the late 1970s, when we couldn't get people to write for the journal. In a period of ten years the culture went from extreme revolutionary optimism to a lack of interest in politics.

J. JACOBSON: When the Vietnam War ended, and the antiwar movement fell apart, it became clear that it was a one-issue movement, and you no longer had that issue. As a result, there was a tremendous wave of demoralization. And the journal was affected by it. We felt that we had to give it up, even though, when we folded, we had 330 library subscriptions.

P. JACOBSON: We did have writers who were attracted by the magazine and wanted to contribute to it. But most of the unsolicited submissions were unusable. The other thing is that while some people seemed to appreciate New Politics 
in the 1970s, it never developed the kind of rapport with its writers that it does right now. We have a number of contributors who have become really dear friends of the magazine, such as Mark Dow, for example, Phil Smith, Steve Steinberg. They'll call and say "I want to write an article." Unfortunately, we weren't able to convince Hal Draper to contribute to the magazine when we started it up again. We had offended Hal, politically, in the 1960s, because we thought it was wrong to start a new sect. We did not think it was the season for that particular vegetable.

WORCESTER: You're referring to...?

P. JACOBSON: The Independent Socialist Clubs, which later became the International Socialists (IS). This was in the late 1960s. We thought that launching a new socialist group was not a great idea, and we did not want to join. He was very angry because we did not join his effort.

WORCESTER: Do you want to say something about where the journal is currently headed? Has it met your expectations since the magazine's relaunch?

P. JACOBSON: I would say that it has more than met my expectations. There's nothing as gratifying as having good writers calling up asking to write on particular topics. But putting it out on a regular basis is still difficult. It's hard to find the necessary resources. You cannot stop promoting the journal.

J. JACOBSON: It's a matter of capitalist economics. You need capital. And we just don't have it. With the money we raise, we can just about come out and maintain what we have, but it's impossible to expand. I figure if we received a lump sum of $\$ 25,000$ or $\$ 30,000$, we could expand the magazine to the point where it would become self-sufficient.

\section{NOTES}

${ }^{1}$ Photo used with permission by Author.

Jon Bloom and Paul Buhle, eds. The Legacy of the Workers Party, 1940-1949:

Recollections and Reflections. New York: Tamiment Institute/Ben Josephson Library, 1985.

James P. Cannon. The Struggle for a Proletarian Party. New York: Pioneer Publishers, 1943.

Lynn Chancer. "A Personal and Political Tribute to Phyllis Jacobson." New Politics, Vol XIII, no. 1 (Summer 2010).

Peter Drucker. Max Shachtman and His Left: A Socialist's Odyssey Through the “American Century." Atlantic Highlands: Humanities Press, 1994. 
60 Worcester

Ernest Haberkern and Arthur Lipow, eds. Neither Capitalism nor Socialism: Theories of Bureaucratic Collectivism. Atlantic Highlands: Humanities Press, 1996.

Sam Farber. "Julius Jacobson (1922-2003)." Against the Current, no. 105 (July/August 2003).

Barry Finger. "Standing Fast: Julius Jacobson.” New Politics, Vol. IX, no. 3 (Summer 2003).

Burton Hall, ed. Autocracy and Insurgency in Organized Labor. Piscataway: Transaction Publishers, 1972.

Irving Howe. A Margin of Hope: An Intellectual Autobiography. New York: Mariner Books, 1984.

Maurice Isserman. If I Had a Hammer: The Death of the Old Left and the Birth of the New Left. New York: Basic Books, 1987.

Julius Jacobson, ed. The Negro and the American Labor Movement. New York: Doubleday, 1968.

Julius Jacobson, ed. Soviet Communism and the Socialist Vision. Piscataway: Transaction Publishers, 1972.

Phyllis and Julius Jacobson, eds. Socialist Perspectives. Princeton: Kaez-Cohl Publishers, 1983.

Max Shachtman. The Bureaucratic Revolution: The Rise of the Stalinist State. New York: Donald Press, 1962.

Harvey Swados. Standing Fast. New York: Doubleday, 1970.

Leon Trotsky. In Defense of Marxism. New York: Pioneer Publishers, 1942.

Alan Wald. The New York Intellectuals: The Rise and Decline of the Anti-Stalinist Left from the 1930s to the 1980s. Chapel Hill: University of North Carolina Press, 1987.

Kent Worcester. C.L.R. James: A Political Biography. Albany: State University of New York Press, 1996. 